Citation: V. Guarnaccia, J. van Niekerk, P. W. Crous, M. SandovalDenis (2021) Neocosmosporaspp. associated with dry root rot of citrus in South Africa. Phytopathologia Mediterranea 60(1):79-100. doi: 10.36253/phyto-12183

Accepted: January 24, 2021

Published: May 15, 2021

Copyright: @ 2021 V. Guarnaccia, J. van Niekerk, P. W. Crous, M. SandovalDenis. This is an open access, peerreviewed article published by Firenze University Press (http://www.fupress. $\mathrm{com} / \mathrm{pm}$ ) and distributed under the terms of the Creative Commons Attribution License, which permits unrestricted use, distribution, and reproduction in any medium, provided the original author and source are credited.

Data Availability Statement: All relevant data are within the paper and its Supporting Information files.

Competing Interests: The Author(s) declare(s) no conflict of interest.

Editor: Alan J.L. Phillips, University of Lisbon, Portugal.

\section{Research Papers \\ Neocosmospora spp. associated with dry root rot of citrus in South Africa}

\author{
Vladimiro GUARNACCIA ${ }^{1,2,3, *}$, Jan VAN NIEKERK ${ }^{3,4}$, Pedro W. CROUS 5 , \\ MARCELO SANDOVAL-DENIS ${ }^{5}$ \\ ${ }^{1}$ Centre for Innovation in the Agro-Environmental Sector, AGROINNOVA, University of \\ Torino, Largo Braccini 2, 10095 Grugliasco (TO), Italy \\ ${ }^{2}$ Department of Agricultural, Forest and Food Sciences (DISAFA), University of Torino, \\ Largo Braccini 2, 10095 Grugliasco (TO), Italy \\ ${ }^{3}$ Department of Plant Pathology, University of Stellenbosch, Private Bag X1, Matieland \\ 7602, South Africa \\ ${ }^{4}$ Citrus Research International, P.O. Box 28, Nelspruit 1200, South Africa \\ ${ }^{5}$ Westerdijk Fungal Biodiversity Institute Uppsalalaan 8, 3584 CT, Utrecht, The Nether- \\ lands \\ ${ }^{\star}$ Corresponding author. E-mail: vladimiro.guarnaccia@unito.it
}

\begin{abstract}
Summary. Citrus is one of the most important fruit crops cultivated in South Africa. Internationally, citrus dry root rot is a common disease in major citrus production areas. Several abiotic and biotic factors are involved in disease development, in which Neocosmospora species are important biotic agents. The diversity of Neocosmospora species associated with dry root rot symptoms of Citrus trees cultivated in South Africa was evaluated using morphological and molecular analyses. Multi-locus analysis was conducted, based on fragments of seven loci including: ATP citrate lyase (acl1), calmodulin (cal), internal transcribed spacer region of the rRNA (ITS), large subunit of the rRNA (LSU), RNA polymerase largest subunit ( $r p b 1)$, RNA polymerase second largest subunit ( $r p b 2)$, and translation elongation factor 1-alpha (tef1). A total of 62 strains representing 11 Neocosmospora species were isolated from crowns, trunks and roots of citrus trees affected by dry root rot, as well as from soils sampled in affected citrus orchards. The most commonly isolated taxa were $N$. citricola, $N$. ferruginea and $N$. solani, while rarely encountered taxa included N. brevis, N. crassa, N. hypothenemi and $N$. noneumartii. Furthermore, four Neocosmospora species are also newly described, namely N. addoensis, N. citricola, N. gamtoosensis and N. lerouxii.
\end{abstract}

Keywords. Citrus decline, morphology, multigene phylogeny, systematics.

\section{INTRODUCTION}

Citrus is one of the most important world fruit crops, and South Afri$\mathrm{ca}$ is among the largest producers and exporters of citrus fruit (FAOSTAT, 2019). Citrus dry root rot (DRR) is a common problem among citrus growers, reported in major production areas such as Australia (Broadbent, 2000), Florida, California and Texas in the United States of America (Graham et 
al., 1985), Italy (Polizzi et al., 1992), Oman (Nemec et al., 1980; Bender, 1985), Pakistan (Kore and Mane, 1992; Conzulex et al., 1997; Verma et al., 1999; Rehman et al., 2012), Turkey (Kurt et al., 2020), Tunisia, Greece and Egypt (El-Mohamedy, 1998; Yaseen and D'Onghia, 2012).

While the aetiology of DRR is multifactorial and not completely understood, it is usually attributed to Neocosmospora (Fusarium) solani sensu lato. However, several species of Neocosmospora, but also Fusarium, are commonly found in orchard soils and citrus plants. These two closely related fusarioid genera encompass important plant pathogens, and are associated with major diseases of citrus (Menge, 1988; Derrick and Timmer, 2000; Sandoval-Denis et al., 2018), including DRR, root rot, feeder root rot, wilt, twig dieback and citrus decline (Menge, 1988; Spina et al., 2008). Fusarium equiseti was recovered from citrus roots in Florida (Smith et al., 1988), while F. proliferatum, F. sambucinum and Neocosmospora solani were found in Greece (MalikoutsakiMathioudi et al., 1987). Fusarium oxysporum f. sp. citri was reported as responsible for the wilt of citrus in Tunisia (Hannachi et al., 2014). Fusarium oxysporum and strains first assigned to " $F$. ensiforme" and later reidentified as Neocosmospora brevis were also reported from DRR in Italy (Sandoval-Denis et al., 2018; 2019), while a number of Neocosmospora species have been reported in association with DRR of citrus in Europe (SandovalDenis et al., 2018).

Neocosmospora (Hypocreales, Nectriaceae), comprises species with varied ecologies, including saprobes, endophytes, and plant and animal pathogens. Pathogenic species of Neocosmospora are known to affect more than 100 plant host families and diverse animal species, including humans (Sandoval-Denis et al., 2019). Although Neocosmospora (1899) is an old and wellestablished name, recent phylogenetic, morphological and ecological data (Lombard et al., 2015) provided additional support for this genus as one of several distinct fusarioid genera in the Nectriaceae. Follow-up revisions have corrected the taxonomy of most Neocosmospora species known to date, including the main pathogenic clades (Sandoval-Denis and Crous, 2018; SandovalDenis et al., 2019).

Previous studies have demonstrated how DRR, caused by the association between stressed plants and Neocosmospora species, can generate sudden decline of plants weakened by abiotic and biotic factors, such as root injuries, Phytophthora root rot, graft incompatibility, poor drainage, poor soil aeration, excess fertilizer, or soil pH (Menge, 1988; Polizzi et al., 1992). Chlorosis, poor vigour, wilt, leaf abscission and degeneration are visible in affected plants for several years before they suddenly die. Examination of scaffold roots, crowns and basal trunks usually shows wood staining (Timmer et al., 1979; Timmer 1982). Rot of the fibrous roots is also visible and associated with canopy size reductions, defoliation, dieback and sloughing of root cortices (Nemec and Baker, 1992). This disease has been managed by planting resistant rootstocks. However, during the last decade, trifoliate orange (Poncirus trifoliata) rootstocks, which are very susceptible to DRR, have been widely used, due to their resistance to virus and soilborne pathogens (i.e.: Citrus Tristeza Virus) (Fang et al., 1998).

Since 2013, sudden, devastating decline and death of citrus trees has been reported in the Gamtoos and Sundays River Valleys production areas in the Eastern Cape province of South Africa. This decline is typically observed on 4- to 10-year-old trees with the trifoliate rootstocks Carrizo citrange and Swingle citrumelo. As scions, these declining trees are of various citrus types, including lemons, oranges and mandarins. To date, little is known about DRR-like diseases in citrus orchards in South Africa. Given the importance of citrus production, and specifically in the two areas of South Afri$\mathrm{ca}$, as well as the relevant economic impact of DRR in other countries, further research was needed to increase understanding of the aetiology of this disease.

Morphological, cultural and molecular characteristics of the fungal species associated with symptomatic trees were investigated in this study by employing largescale sampling to isolate the pathogens involved, and to identify their strains according to modern taxonomic concepts via morphological characterization and multilocus DNA sequence data. In 2018 several surveys were conducted in citrus orchards with the aims to: (1) conduct extensive surveys to sample symptomatic plant material; (2) cultivate as many of the associated fungi as possible; (3) conduct DNA multi-locus sequence analyses combined with morphological characterization of isolates obtained; and (4) compare the obtained results with known wood decay fungi previously associated with trees displaying characteristic DDR symptoms.

\section{MATERIALS AND METHODS}

\section{Sampling, fungal collection and isolation}

The Patensie (Gamtoos River Valley) and Kirkwood (Sundays River Valley) areas were surveyed during the second half of 2018. During these visits, the external and internal symptoms of diseased trees were examined. Scaffold roots, crown and trunk portions taken from between soil level and scion unions, were collected in 
both the survey areas. Samples were each transversally cut into 3-cm-thick discs, which allowed observation of internal wood decay symptoms.

Wood fragments $(3 \times 3 \mathrm{~mm})$ were cut from necrotic and healthy tissues and also from the margins between them. Each fragment was then surface sterilised by soaking in $70 \%$ ethanol for $5 \mathrm{~s}, 4 \%$ sodium hypochlorite for $90 \mathrm{~s}$, sterile water for $60 \mathrm{~s}$ and then dried on sterile filter paper. Fragments were placed on potato dextrose agar (PDA) amended with $100 \mu \mathrm{g} \mathrm{mL}^{-1}$ streptomycin (PDA-S), and were then incubated at $25^{\circ} \mathrm{C}$. Characteristic Neocosmospora colonies were collected from these plates by hyphal tipping onto clean PDA-S plates. The isolates used in this study are maintained in the culture collection of the Department of Plant Pathology, University of Stellenbosch, Stellenbosch, South Africa, and at the Westerdijk Fungal Biodiversity Institute (CBS), Utrecht, The Netherlands (Table 1).

\section{Morphological studies of isolates}

Morphological studies were carried out as indicated elsewhere (Leslie and Summerell, 2006; Sandoval-Denis and Crous, 2018; Sandoval-Denis et al., 2019). Macroscopic characteristics and fungal colony appearance of each isolate was determined after culturing on oatmeal agar (OA), potato dextrose agar (PDA) and synthetic nutrient-poor agar (SNA; Nirenberg, 1976), and incubation for $7-14 \mathrm{~d}$ at $24^{\circ} \mathrm{C}$ in darkness under a $12 \mathrm{~h} / 12$ h light/darkness cycle using cool fluorescent light. Colour nomenclature follows that of Rayner (1970). Fungal micromorphology was studied using 7-14-d-old cultures on carnation leaf agar (CLA; Fisher et al., 1982) and SNA, incubated at $24^{\circ} \mathrm{C}$ in a $12 \mathrm{~h} / 12 \mathrm{~h}$ near UV light/ dark cycle. Photomicrographs were captured using a Nikon Eclipse 80i microscope with Differential Interference Contrast (DIC) optics and a Nikon AZ100 dissection microscope, both equipped with a Nikon DS-Ri2 high definition colour digital camera. Measurements were recorded using Nikon NIS-elements D software v. 4.50, from at least 50 randomly selected elements for each structure.

\section{Molecular studies of isolates}

Total genomic DNA was extracted from isolates grown on malt extract agar (MEA; Crous et al., 2019), incubated for $7 \mathrm{~d}$ at room temperature (approx. $24^{\circ} \mathrm{C}$ ). Mycelium was scraped from the colony surfaces with the aid of sterile scalpels, and DNA was isolated using the Wizard ${ }^{\circledR}$ Genomic DNA purification Kit (Promega Cor- poration) following the manufacturer's protocol.

Seven gene fragments were PCR amplified using the following primer combinations with protocols described elsewhere: acl1-230up and acl1-1220low for the larger subunit of the ATP citrate lyase (acl1; Gräfenhan et al. 2011), CAL-228F and CAL2Rd for calmodulin (cal; Carbone and Kohn, 1999; Quaedvlieg et al., 2014), ITS4 and ITS5 for the internal transcribed spacer region of the rRNA (ITS; White et al., 1990), LR0R and LR5 for a partial fragment of the large subunit of the rRNA (LSU; Vilgalys and Hester, 1990; Vilgalys and Sun, 1994), Fa and G2R for the RNA polymerase largest subunit ( $r p b 1$; O'Donnell et al., 2010), 5f2 and 7cr plus 7cf and 11ar for two non-contiguous fragments of the RNA polymerase second largest subunit (rpb2: Liu et al., 1999; Sung et al. 2007), and EF-1 and EF-2 for the translation elongation factor 1-alpha gene (tef1: O'Donnell et al., 2008). Sequencing was carried out in both directions on an ABI Prism 3730XL DNA Analyzer (Applied Biosystems) using the same primer pairs used for amplification, plus the internal sequencing primers F6, F8 and R8 for rpb1 (O’Donnell et al., 2010). Consensus sequences were assembled using Seqman Pro v. 10.0.1 (DNASTAR).

Sequence alignments were constructed and analysed individually for each gene partition, including DNA sequences representing the phylogenetic diversity of Neocosmospora selected according to recently published phylogenies (Guarnaccia et al., 2019; Sandoval-Denis et al., 2019). Alignments were achieved using MAFFT (Katoh et al., 2019) as implemented on the European Bioinformatics Institute (EMBL-EBI) portal (www.ebi. ac.uk), and were visually inspected and then manually corrected if needed using MEGA v. 6 (Tamura et al., 2013).

Phylogenetic analyses were based on two independent algorithms: Maximum-Likelihood, using Random Accelerated (sic) Maximum Likelihood (RAxML) v. 8.2.10 (Stamatakis, 2014) and Bayesian inference (BI) under MrBayes v. 3.2.6 (Huelsenbeck and Ronquist, 2001; Ronquist and Huelsenbeck, 2003). The analyses were carried out using the CIPRES Science Gateway portal (www. phylo.org: Miller et al., 2012). Single-gene phylogenies were compared visually to check for topological conflict between significantly supported clades, and then as combined multilocus phylogenies (Mason-Gamer and Kellogg, 1996; Wiens 1998). A first analysis based on combined rpb2 and tef1 sequence data was directed to identify Neocosmospora spp. from isolates obtained from symptomatic citrus trees. A second analysis including the combined seven gene dataset was directed to clarify the phylogeny of South African citrus Neocosmospora isolates with uncertain phylogenetic position or deter- 


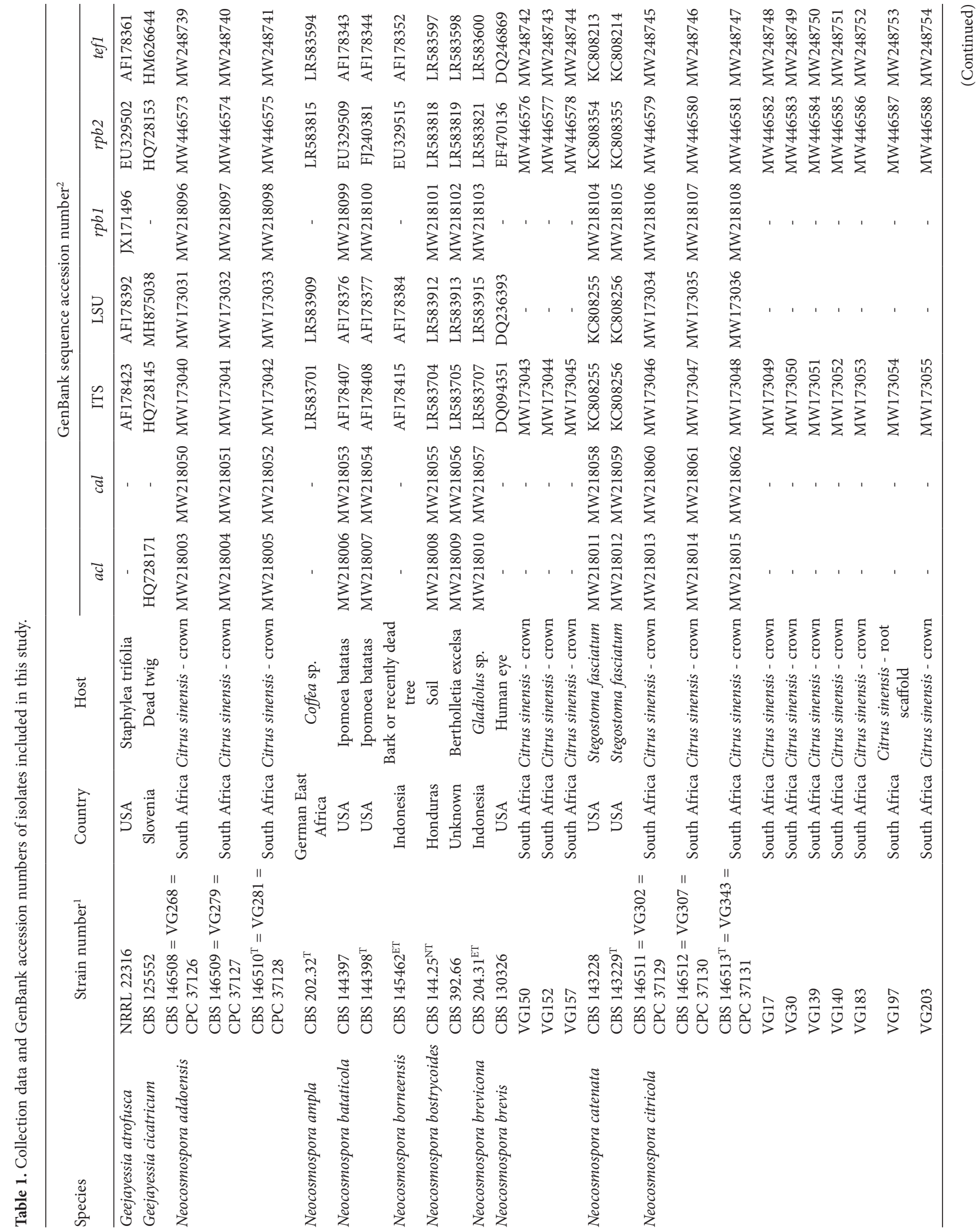




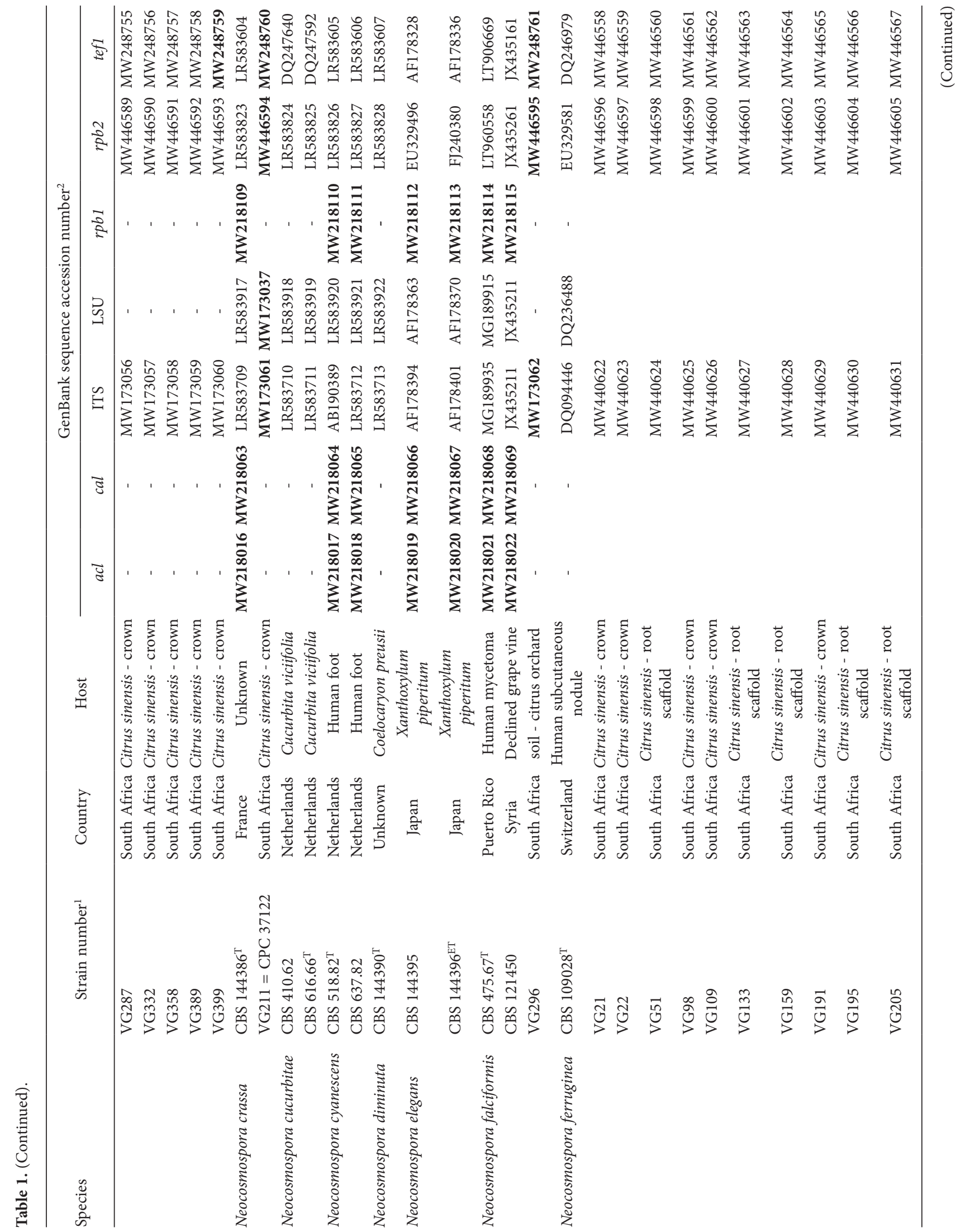




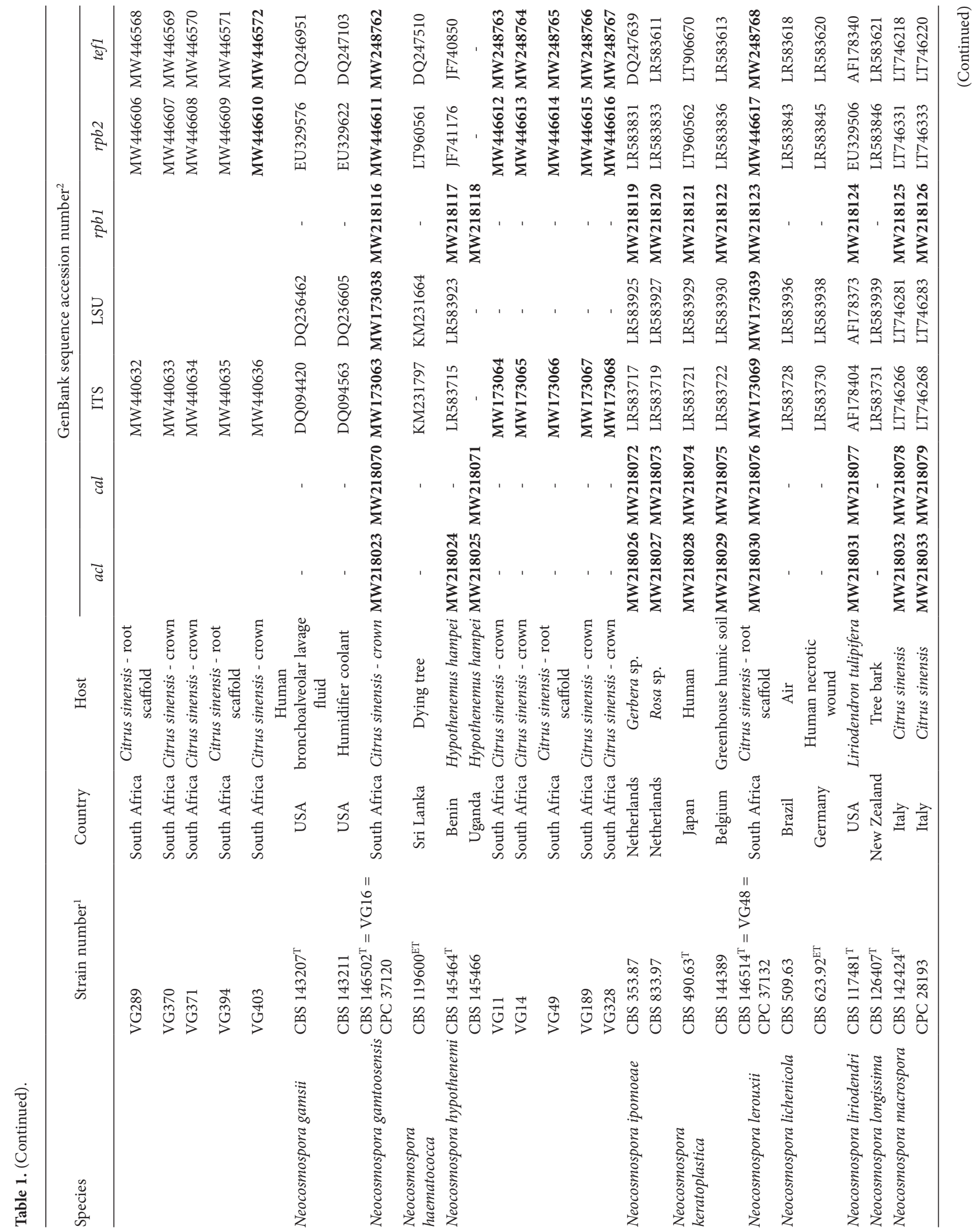




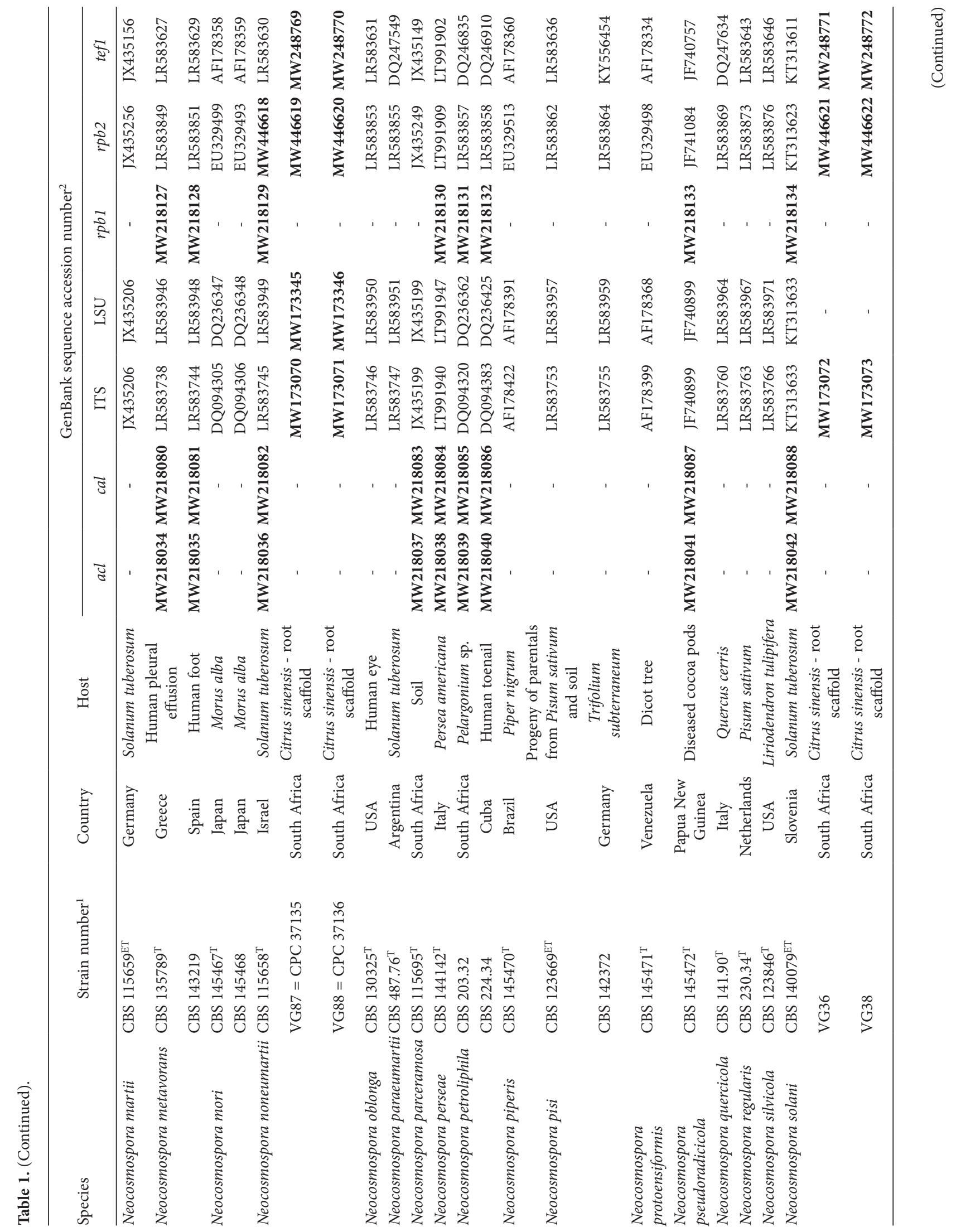




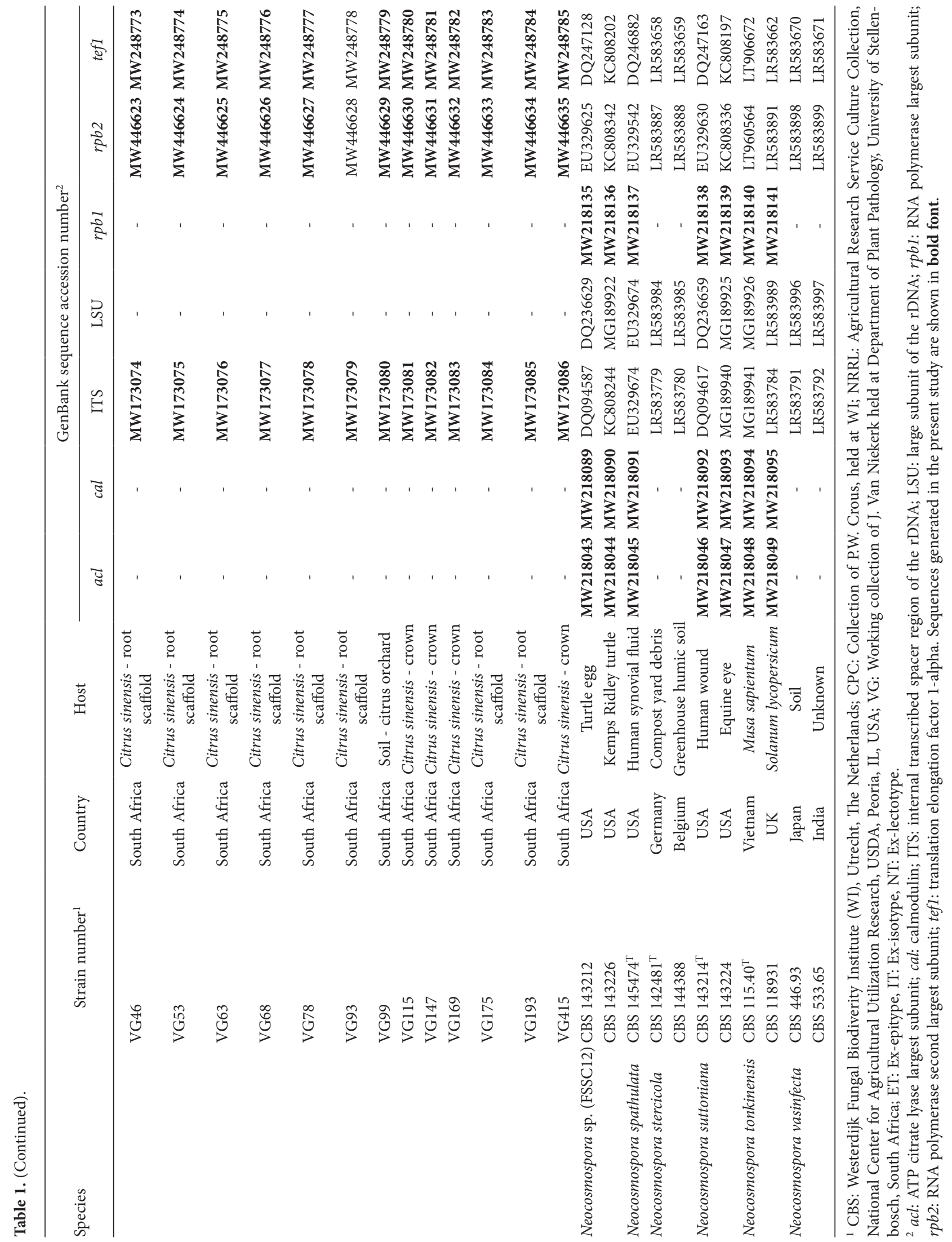


mined as putative novel species in the previous analyses. For RAxML analyses, the default parameters were selected and clade stability was determined by bootstrap (BS) analysis using 1000 repetitions. Bayesian analyses consisted of two parallel runs of $5 \mathrm{M}$ generations, with the stop-rule on, set to 0.01 . The sampling frequency was set to 1000 generations, and consensus trees and posterior probability values (PP) were calculated after discarding the first $25 \%$ of sampled trees as the burn-in fraction. The best evolutionary model for each gene partition was determined using MrModelTest v. 2.3 (Nylander, 2004).

\section{RESULTS}

\section{Sampling, fungal collection and isolation}

In the Patensie and Kirkwood areas, diseased trees initially showed yellowing, wilting leaves and dieback of branch tips. Symptoms subsequently progressed with defoliation and sudden decline before the plants died. Inspection of affected trees showed cracks or blisters on the trunks above the crowns with, rarely, gum exudates (Figure 1). If each trunk was transversely cut, brown to black discolouration and necrosis of the vascular tissue became visible with different extensions (Figure 2). Similar discolouration and stains were visible into the scaffold roots. Symptoms were observed in orchards older than 8 years. Incidence of symptomatic plants was in some cases up to $50 \%$ of affected trees in orchards.

A total of 62 monosporic isolates resembling those of Neocosmospora were collected from the sampled citrus trees. Among them, 33 isolates were obtained from the Kirkwood area and 29 from Patensie. Thirty-eight were isolated from trunk portions, 22 from scaffold roots, and two from soil surrounding infected roots. Among the isolates collected from trunks, 17 were from necrotic tissue, two from healthy tissue and 14 from the margins between necrotic and healthy tissues.

\section{Phylogenetic studies and identification of the pathogens}

A first analysis, based on combined rpb2 and tef1 loci, was conducted to identify the Neocosmospora isolates obtained from symptomatic citrus trees. The dataset contained 129 isolates, representing 62 South African isolates, as well as 67 ex-type or reference strains representing 46 taxa in Neocosmospora, and two outgroup taxa (Geejayessia atrofusca NRRL 22316 and G. cicatricum CBS 125552). The alignment included 2290 positions (1614 rpb2, $676 \mathrm{tefl})$ of which 748 were variable (480 rpb2, 268 tefl), and 562 positions were phyloge- netically informative sites (379 rpb2, 183 tef1). For both gene partitions, a GTR + I + G model was selected and incorporated in the analyses. The BI lasted for $1,855,000$ generations, and the consensus tree and PP were calculated from 1392 trees after discarding 494 trees as burn-in fraction. Phylogenetic trees inferred using ML and $\mathrm{BI}$ analyses resulted in very similar topologies, and therefore only the ML tree is presented in Figure 3a. The South African isolates were distributed among 11 distinct phylogenetic lineages, of which seven corresponded to known Neocosmospora species, which were, in order of frequency of isolation: $N$. ferruginea and $N$. solani (15 isolates each), N. hypothenemi (five isolates), N. brevis (three isolates), $N$. noneumartii (two isolates), and $N$. crassa and $N$. falciformis (one isolate each). The remaining 20 South African isolates grouped within four undescribed phylogenetic lineages, among which 15 isolates clustered in a well-supported clade ("Neocosmospora sp. $1 "$, BS $=93 / \mathrm{PP}=0.96)$, sister to $N$. bataticola; three isolates (VG268, 279 and 281) clustered in a fully-supported clade ("Neocosmospora sp. 2", BS =100/PP = 100), sister to N. metavorans; while two isolates (singletons VG16 and VG48) were resolved as single lineages (respectively, "Neocosmospora sp. 3" and "Neocosmospora sp. 4"); however, with low statistical support values compared with those in the rpb2 and tef1 analyses.

To further assess the phylogenetic position of the putative novel phylogenetic clades, a second, more robust multi-locus phylogenetic analysis was performed using seven loci ( $a c l, c a l$, ITS, LSU, rpb1, rpb2 and tef1) and selected strains representing closely related species, as determined in the previous phylogenetic assessment of the genus Neocosmospora. The combined dataset included 5904 positions (616 acl, $573 \mathrm{cal}, 467$ ITS, 480 LSU, 1489 $r p b 1,1613$ rpb2 and 666 tef1) from 47 strains, representing a subset of 28 phylogenetic clades of Neocosmospora, plus two outgroup taxa. From the total sites included, 1405 were variable (188 acl, $103 \mathrm{cal}, 100$ ITS, $34 \mathrm{LSU}$, $372 r p b 1,390 r p b 2$ and 218 tef1), and 856 were phylogenetically informative $(81 \mathrm{acl}, 82 \mathrm{cal}$, 70 ITS, 22 LSU, 196 $r p b 1,266 r p b 2$ and 139 tef1). Optimal model selection for each gene partition was determined as follows: GTR + G for tef1, GTR + I + G for LSU and ITS; K80 + G for acl, $\mathrm{K} 80+\mathrm{I}+\mathrm{G}$ for $c a l$, and SYM + I + G for $r p b 1$ and $r p b 2$. The BI lasted for 1,520,000 generations, and PP were calculated from 1141 trees after discarding 380 trees as the burn-in fraction. The BI analysis (shown in Figure 3 b) confirmed the topology obtained by ML.

The analyses confirmed the results obtained in the two-gene phylogeny, and the four novel lineages were resolved with high BS and PP support. Neocosmospora sp. 2 and representative isolates of clade Neocosmospora 

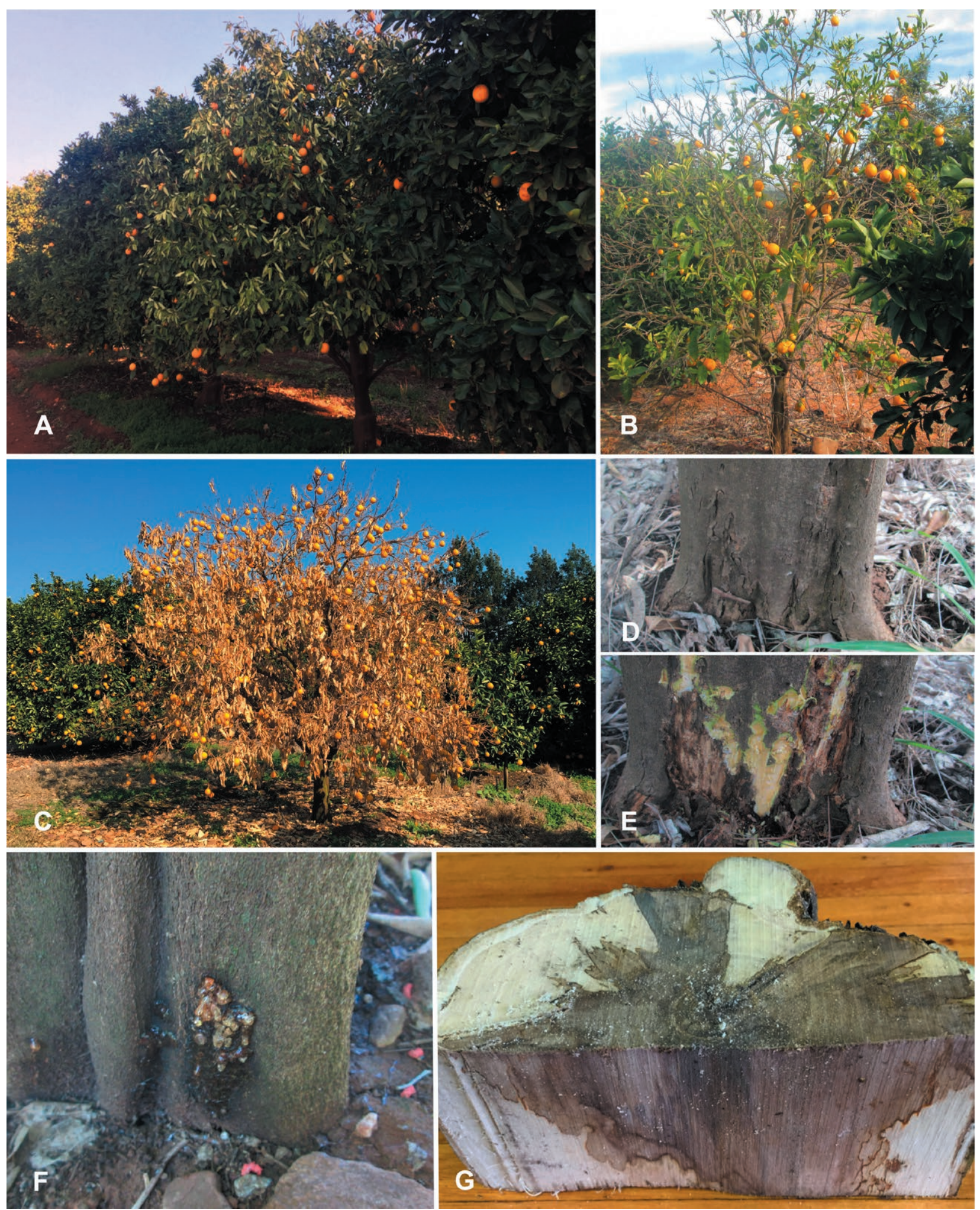

Figure 1. Dry root rot symptoms of citrus observed in South Africa. Tree decline progression: initial leaves wilting (A), yellowing, loss of leaves, and dieback of branch tips (B) and plant death (C). External cracks or blisters on the trunk portion above the crown (D) and internal dry rot (E) of the same plant. Gum exudate at the crown level (F). Brown to black discolouration and necrosis of the vascular tissue visible in longitudinal and transverse sections $(\mathrm{G})$. 

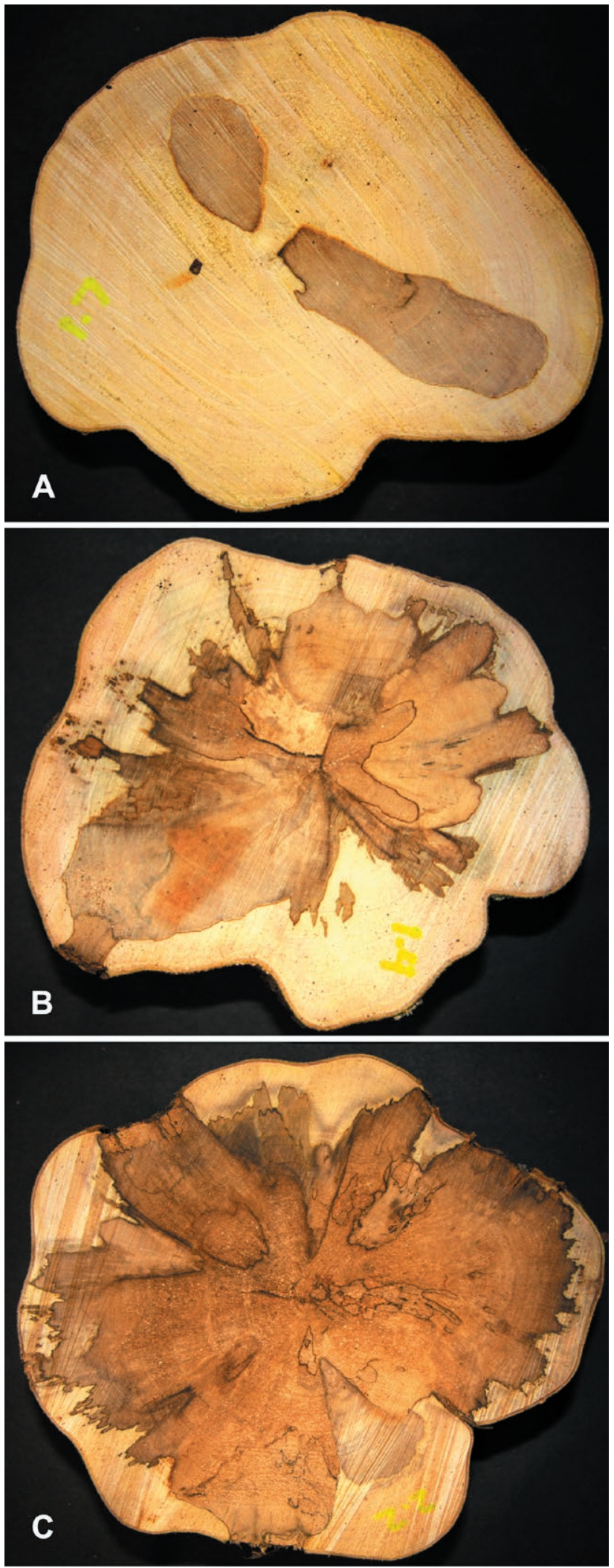

Figure 2. Small (A), medium (B) or large (C) extensions of internal discolouration in transverse sections through citrus tree trunks. sp. 1 were both resolved as fully supported clades $(\mathrm{BS}=$ $100 / \mathrm{PP}=100$ ), while the lone lineages Neocosmospora sp. 3 and Neocosmospora sp. 4 were confidently resolved as well-supported branches (respectively, BS $=96 / \mathrm{PP}=0.97$ and $\mathrm{BS}=86 / \mathrm{PP}=0.96$ ). These four phylogenetic lineages are therefore here proposed as the novel species Neocosmospora addoensis, N. citricola, N. gamtoosensis and N. lerouxii.

\section{Taxonomy}

Neocosmospora addoensis Sand.-Den. \& Guarnaccia, sp. nov. - MycoBank MB837939; Figure 4.

Etymology. Named after the geographical area Addo, South Africa where first collected.

Typus. South Africa, Eastern Cape, Kirkwood, from Citrus sinensis crown, May 2018, V. Guarnaccia (holotype CBS H-24565 designated here, culture ex-type CBS $146510=$ CPC $37128=$ VG281).

Conidiophores borne on aerial mycelium, 53.5$425 \mu \mathrm{m}$ long, unbranched or less commonly laterally branched, bearing terminal single phialides, proliferating percurrently; aerial phialides monophialidic, subulate to subcylindrical, smooth- and thin-walled, 34-64.5 × 2-4 $\mu \mathrm{m}$, with short and flared apical collarettes and inconspicuous periclinal thickening; aerial conidia arranged in false heads on phialide tips, hyaline, broadly ellipsoidal to clavate and slightly asymmetrical, smooth- and thinwalled, aseptate, (5.5-)7-10(-14.5) $\times(2-) 3-4 \mu \mathrm{m}$ (av. 8.5 $\times 3 \mu \mathrm{m})$. Sporodochia pale luteous to pale peach coloured, formed abundantly on carnation leaves. Sporodochial conidiophores unbranched or laterally and irregularly branched bearing apical groups of 2-3 monophialides; sporodochial phialides subulate to subcylindrical, 12.5-25 $\times 2-4.5 \mu \mathrm{m}$, smooth and thin-walled, commonly proliferating sympodially, collarettes and periclinal thickening absent or inconspicuous. Sporodochial conidia falcate, slightly curved dorsoventrally to almost straight, broadest near the half portion or the upper third, tapering towards both ends, with blunt and slightly curved apical cells and blunt, sometimes inconspicuous foot-like basal cells, (1-)2-5-septate, predominantly 4-septate, hyaline, smooth- and thick-walled; one-septate conidia: (18.5-)19$24(-25) \times 3-4.5 \mu \mathrm{m}$ (av. $21.5 \times 4 \mu \mathrm{m})$; two-septate conidia: $(24-) 26-30 \times 3.5-5 \mu \mathrm{m}$ (av. $27.5 \times 4.5 \mu \mathrm{m}$ ); three-septate conidia: (27-)33-43(-45) $\times(3-) 4-5.5(-6) \mu \mathrm{m}$ (av. 38 $\times 5 \mu \mathrm{m})$; four-septate conidia: $(39-) 42-47.5(-51.5) \times 4.5-$ $6 \mu \mathrm{m}$ (av. $49 \times 5.5 \mu \mathrm{m}$ ); five-septate conidia: (37.5-)42.5$51 \times 5-6 \mu \mathrm{m}$ (av. $47 \times 5.5 \mu \mathrm{m})$. Chlamydospores subspherical to spherical, hyaline to pale yellow, smooth-walled or slightly roughened, thick-walled, $4-10 \mu \mathrm{m}$, single or in chains, terminal or intercalary on hyphae and conidia. 


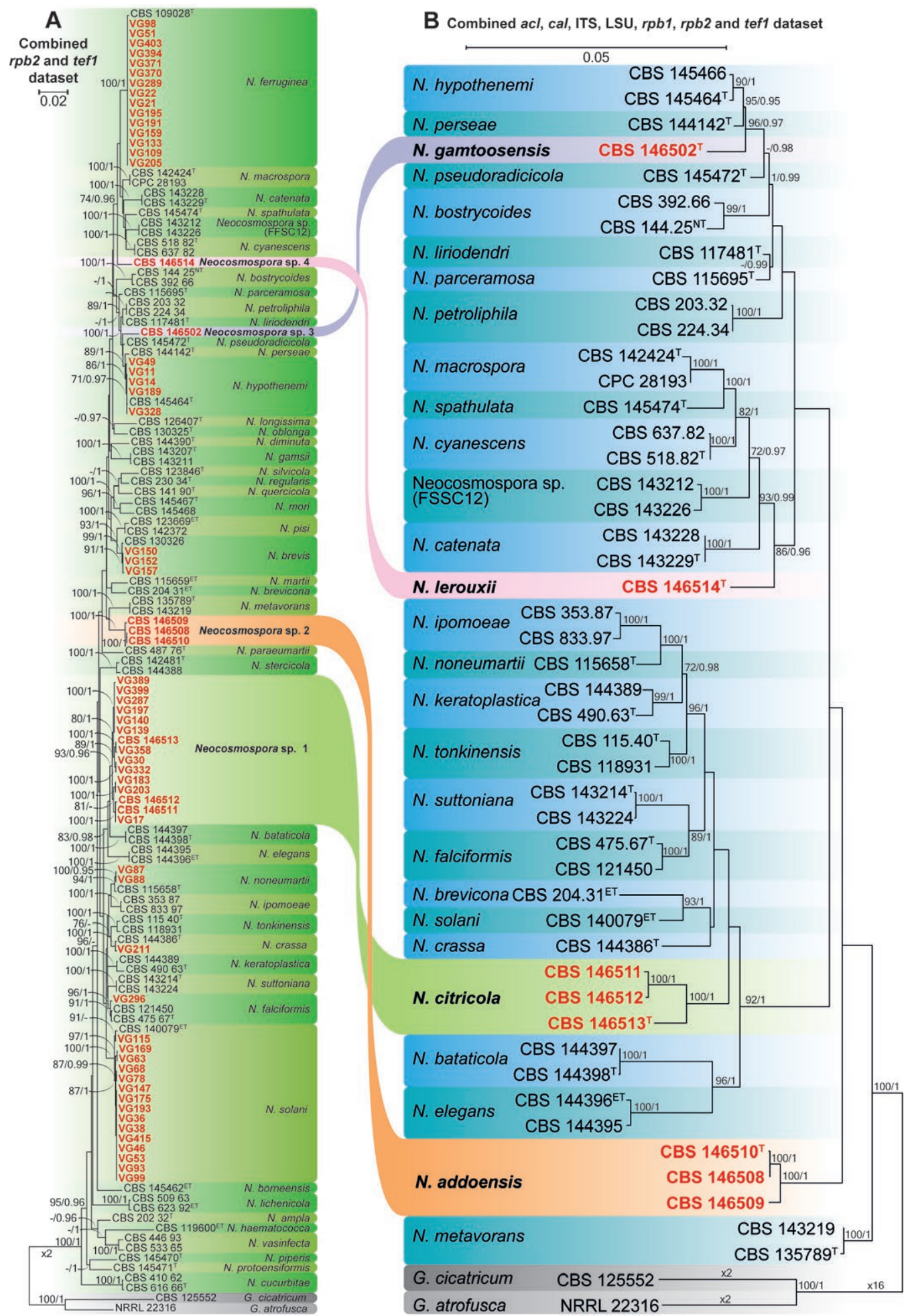

Figure 3. Maximum-likelihood (ML) phylograms obtained from combined $r p b 2$ and tef1 (A) and acl, cal ITS, LSU, $r p b 1, r p b 2$ and tef1 (B) sequences, of 62 isolates of Neocosmospora spp. from South African Citrus (shown in red), and representative and ex-type isolates of Neocosmospora. Names of new species described here are shown in bold font. Numbers on the nodes are ML bootstrap values greater than $70 \%$ followed by Bayesian posterior probability values greater than 0.95 . Branch lengths are proportional to distance. Ex-type, ex-epitype and ex-neotype strains are indicated, respectively, with ${ }^{\mathrm{T}}$, ${ }^{\mathrm{ET}}$ and ${ }^{\mathrm{NT}}$. The trees are rooted to Geejayesia atrofusca (NRRL 22316 and G. cicatricum (CBS 125552). 

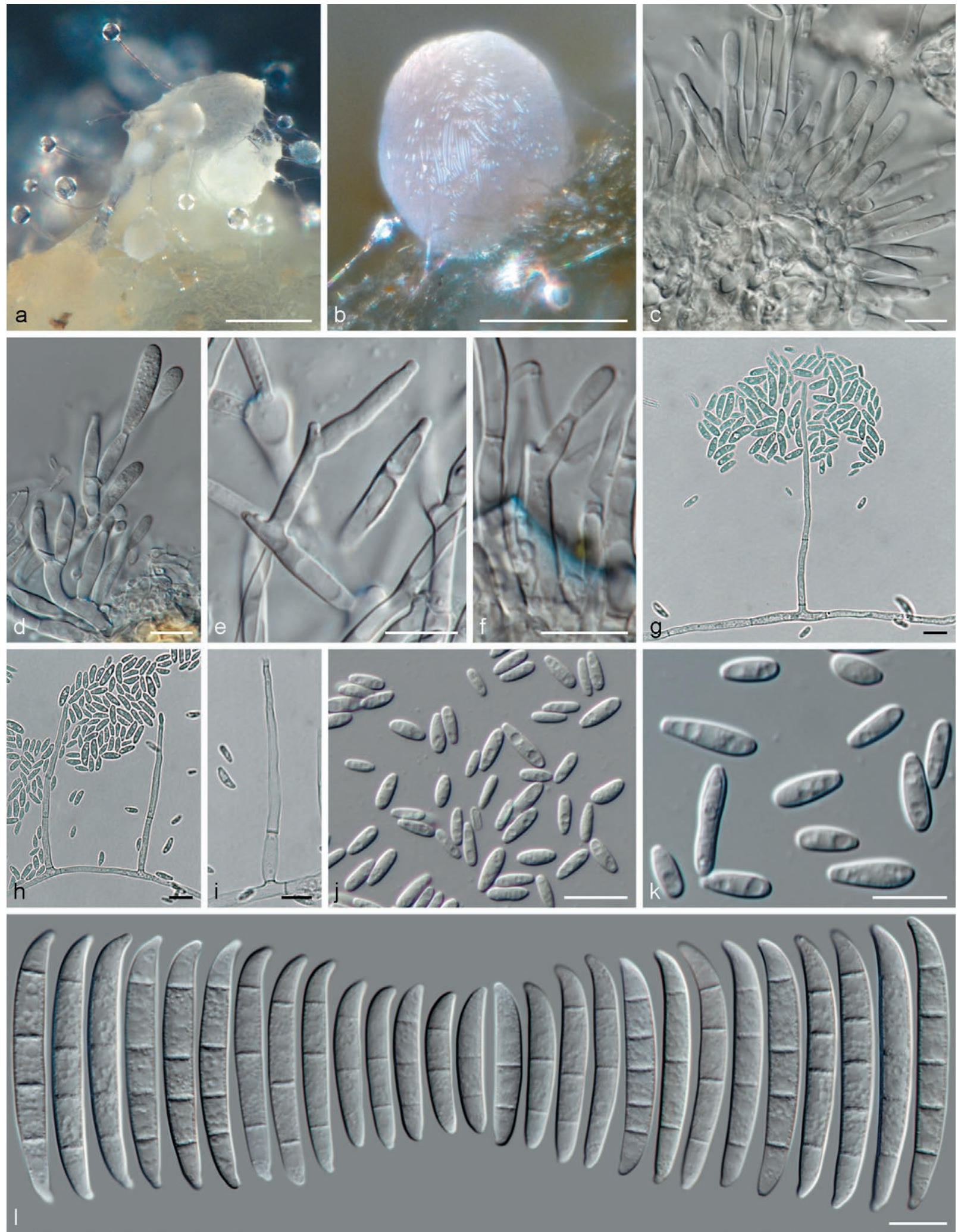

Figure 4. Neocosmospora addoensis (ex-type culture CBS 146510). (a and b) sporodochia formed on the surface of carnation leaves; (c to f) sporodochial conidiophores and phialides; ( $g$ to i) aerial conidiophores; ( $j$ and k. aerial conidia; (l) sporodochial conidia. Scale bars: a and b $=100 \mu \mathrm{m} ; \mathrm{c}$ to $\mathrm{l}=10 \mu \mathrm{m}$. 
Culture characteristics. Colonies on PDA reaching 79 $\mathrm{mm}$ diam. at $24^{\circ} \mathrm{C}$ after $7 \mathrm{~d}$ (growth rate: $4.1-5.6 \mathrm{~mm}$ $\mathrm{d}^{-1}$ ). Colony surface white to primrose, becoming scarlet to bay, flat with abundant dense aerial mycelium, cottony to woolly; colony reverse pale luteous to sulphur yellow, a vivid scarlet to rust pigment can be formed. On SNA, white to pale buff, membranous to woolly with scant aerial mycelium, becoming powdery; colony reverse white to pale buff. On OA, pale luteous to pale rosy buff, flat, membranous to cottony; colony reverse pale luteous to pale rosy buff.

Additional materials examined. South Africa, Eastern Cape, Patensie, from Citrus sinensis crown, May 2018, V. Guarnaccia (CBS $146508=$ CPC $37126=$ VG 268, CBS $146509=$ CPC $37127=$ VG279).

Notes. Both phylogenetic analyses resolved Neocosmospora addoensis as the closest genetic relative to $\mathrm{N}$. metavorans (96 to $98 \%$ sequence similarity among individual gene datasets). Neocosmospora metavorans is a frequent opportunistic pathogen of animals, including humans (Sandoval-Denis et al., 2019). Nevertheless, in addition to its genetic exclusivity, these two species are morphologically quite distinct, particularly in the size and septation of the aerial conidia (aseptate, up to 14.5 $\mu \mathrm{m}$ in $N$. addoensis and multiseptate, up to $25 \mu \mathrm{m}$ in $N$. metavorans), while sporodochial conidia of $N$. addoensis are more slender (up to $6 \mu \mathrm{m}$ wide) than those of $N$. metavorans (up to $7.5 \mu \mathrm{m}$ wide).

Neocosmospora addoensis is characterized by its small and slender macroconidia, which are much smaller than the average macroconidial type in Neocosmospo$\mathrm{ra}$. Based on its macroconidial size, this species is close to N. brevis and N. pseudoradicicola; however, these two species are well-delimited phylogenetically, clustering in far separate lineages of the genus (96\% sequence similarity with $N$. brevis and $97 \%$ with $N$ pseudoradicicola). Morphologically, N. addoensis differs from N. pseudoradicicola by its macroconidial shape and curvature, with more rounded apical cells, rather inconspicuous foot cells and less pronounced dorsoventral curvature; and from N. brevis by the absence of aerial macroconidia and slightly more elongated and hooked macroconidial apical cells.

Neocosmospora citricola Guarnaccia \& Sand.-Den., sp. nov. - MycoBank MB837940; Figure 5.

Etymology. In reference to occurrence of this fungus on Citrus plants.

Typus. South Africa, Eastern Cape, Patensie, from Citrus sinensis crown, May 2018, V. Guarnaccia (holotype CBS H-24566 designated here, culture ex-type CBS $146513=$ CPC $37131=$ VG343).
Conidiophores borne on aerial mycelium, 66.5-198.5 $\mu \mathrm{m}$ long, unbranched or irregularly laterally branched, bearing terminal single phialides; aerial phialides monophialidic, subulate to subcylindrical, smooth- and thinwalled, 39.5-73.5 $\times 2-4.5 \mu \mathrm{m}$, each showing a discrete flared collarette and inconspicuous to evident periclinal thickening; aerial conidia arranged in false heads on phialide tips, hyaline, broadly ellipsoidal to obovoidal, rarely clavate, smooth- and thin-walled, 0 -1-septate, (6-)9-17(-24.5) × 3-5(-6.5) $\mu \mathrm{m}$ (av. $13 \times 4.5 \mu \mathrm{m})$. Sporodochia pale luteous to pale orange, formed abundantly on carnation leaves and on the agar surface. Sporodochial conidiophores laterally and irregularly branched, bearing single terminal monophialides or terminal groups or up to three monophialides; sporodochial phialides subulate to subcylindrical, $11-27.5 \times 3-5.5 \mu \mathrm{m}$, smooth and thin-walled, with inconspicuous or absent apical collarettes and periclinal thickening. Sporodochial conidia falcate, curved dorsoventrally to almost straight, each with broadening in the upper third, tapering towards both ends, with a blunt to papillate and slightly curved apical cell and a blunt, foot-like basal cell, (2-)3-5(-6)-septate, predominantly five-septate, hyaline, robust, smooth- and thick-walled; two-septate conidia, $44 \times 5.7 \mu \mathrm{m}$; three-septate conidia: $33.5-49.5(-58) \times 4.5-6 \mu \mathrm{m}$ (av. $43 \times 5.5 \mu \mathrm{m})$; four-septate conidia: $(46.5-) 47.5-56(-59.5) \times 5-6.5 \mu \mathrm{m}$ (av. $52 \times 6 \mu \mathrm{m})$; five-septate conidia: (49.5-)53-60.5(-65) $\times(4.5-) 5.5-6.5(-7) \mu \mathrm{m}$ (av. $57 \times 6 \mu \mathrm{m})$; six-septate conidia: $60 \times 6 \mu \mathrm{m}$. Chlamydospores subspherical to spherical, hyaline to pale golden brown, smooth to slightly roughened and thick-walled, 5-10 $\mu \mathrm{m}$, single or in chains, terminal or intercalary on hyphae and conidia.

Culture characteristics: Colonies on PDA reaching $69 \mathrm{~mm}$ diam. at $24^{\circ} \mathrm{C}$ after $7 \mathrm{~d}$ (growth rate: $3.2-4.9$ $\mathrm{mm} \mathrm{d}^{-1}$ ). Colony surfaces straw, buff to pale luteous, with pale luteous to orange centres and abundant aerial mycelium, flat, felty, woolly to cottony with abundant concentric rings of aerial mycelium, colony reverse pale luteous to orange. On SNA, white and translucent, flat, woolly, becoming slightly pulverulent with sporulation, colony reverse white. On OA, saffron to peach, flat, membranous to cottony, colony reverse intense peach to flesh.

Additional materials examined. South Africa, Eastern Cape, Patensie, from Citrus sinensis crown, May 2018, V. Guarnaccia (CBS $146511=$ CPC $37129=$ VG302, CBS $146512=$ CPC $37130=$ VG307).

Notes. Neocosmospora citricola resolved as a highly supported monophyletic clade, basal to a fully supported lineage containing $N$. bataticola and $N$. elegans, which clearly differentiated genetically (96 to $98 \%$ sequence similarity to $N$. citricola in the single gene datasets). 

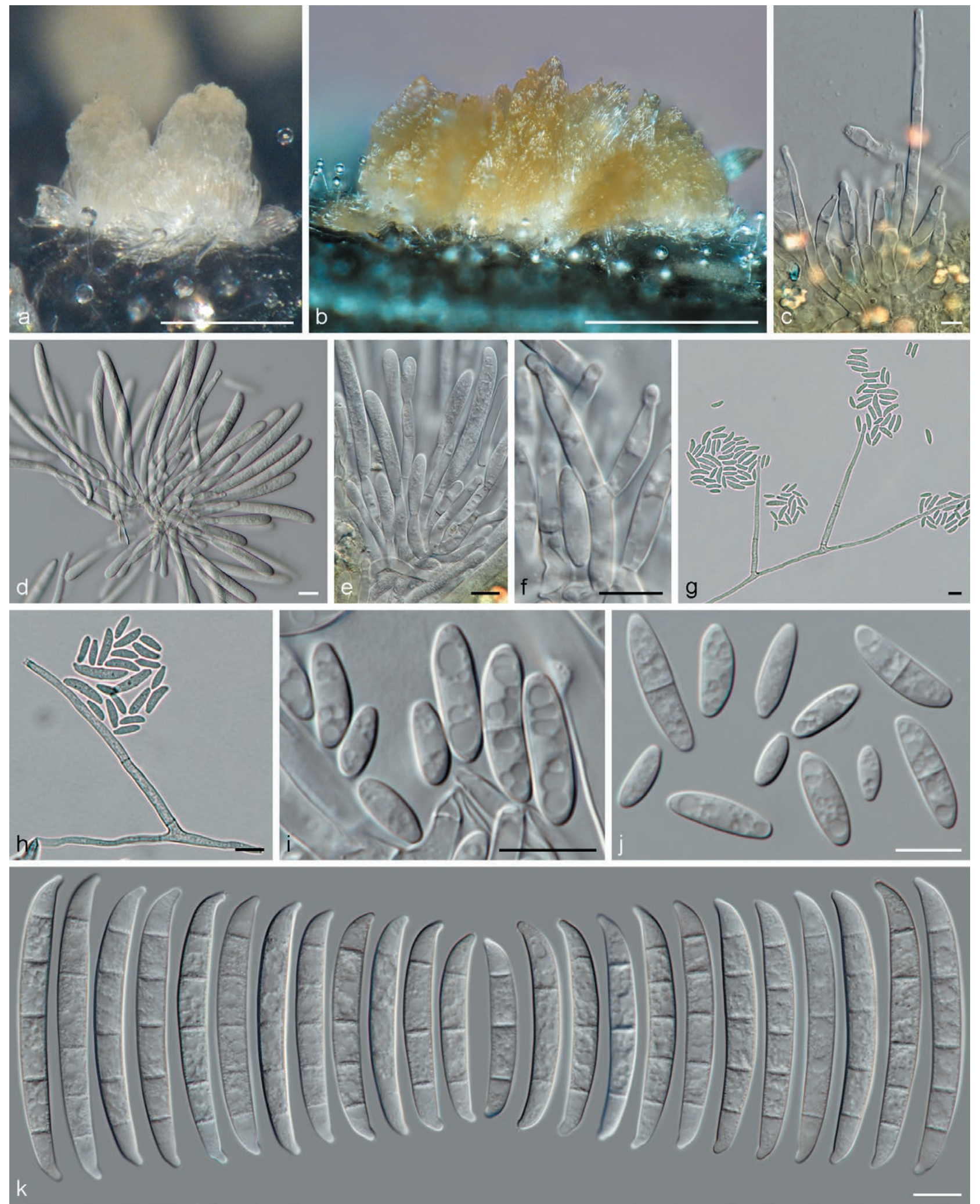

Figure 5. Neocosmospora citricola (ex-type culture CBS 146513). (a and b) sporodochia formed on the surface of carnation leaves; (c to f) sporodochial conidiophores and phialides; ( $\mathrm{g}$ and $\mathrm{h}$ ) aerial conidiophores; ( I and j) aerial conidia; (k) sporodochial conidia. Scale bars: a and $\mathrm{b}=100 \mu \mathrm{m} ; \mathrm{c}$ to $\mathrm{k}=10 \mu \mathrm{m}$. 
Although genetically distant, Neocosmospora citricola is morphologically similar to $N$. nirenbergiana, $N$. piperis and $N$. protoensiformis (92\% sequence similarity with $N$. nirenbergiana and $96 \%$ with $N$. piperis and $N$. protoensiformis; data not shown), the four species producing very similar macroconidia in shape and overall size. Nevertheless, $N$. citricola differs from $N$. nirenbergiana and $N$. piperis by the absence of aerial macroconidia. Conversely, N. nirenbergiana and $N$. piperis do not produce aerial microconidia, and the aerial conidiophores of $N$. citricola are much more robust than those of $N$. nirenbergiana and N. piperis. Neocosmospora protoensiformis also lacks aerial macroconidia; however, in addition to forming smaller microconidia (up to $15 \mu \mathrm{m}$ long, average size $7.6 \times 3.6 \mu \mathrm{m}$ in $N$. protoensiformis $v$ s up to 24 $\mu \mathrm{m}$ long, average size $13 \times 4.5 \mu \mathrm{m}$ in $N$. citricola), and shorter sporodochial phialides (up to $19.5 \mu \mathrm{m}$ long in $N$. protoensiformis $v$ s up to $27.5 \mu \mathrm{m}$ long in N. citricola), macroconidia of $N$. protoensiformis differ from those of $N$. citricola by usually being more tapered at both ends.

Neocosmospora gamtoosensis Sand.-Den. \& Guarnaccia, sp. nov. - Mycobank MB837941; Figure 6.

Etymology. Named after the valley where this fungus was collected, Gamtoos River Valley, South Africa.

Typus. South Africa, Eastern Cape, Patensie, from Citrus sinensis crown, May 2018, V. Guarnaccia (holotype CBS H-24564 designated here, culture ex-type CBS $146502=$ CPC $37120=$ VG16).

Conidiophores borne on aerial mycelium, 96.5-291 $\mu \mathrm{m}$ long, unbranched or irregularly laterally branched, bearing terminal single phialides; aerial phialides monophialidic, subulate to subcylindrical, smooth- and thinwalled, $17.5-61 \times 2-3.5 \mu \mathrm{m}$, collarettes and periclinal thickening evident; aerial conidia arranged in false heads on phialide tips, hyaline, broadly ellipsoid, obovoid to short clavate, smooth- and thin-walled, aseptate, $(4.5-) 5.5-9(-11.5) \times 2-3.5(-6) \mu \mathrm{m}$ (av. $7 \times 3 \mu \mathrm{m})$. Sporodochia citrine to honey, formed abundantly on carnation leaves. Sporodochial conidiophores commonly unbranched and densely packed, bearing terminal, single monophialides or groups of 2-3 phialides; sporodochial phialides lageniform to ampulliform, 7.5-17 $\times$ 3-5 $\mu \mathrm{m}$, smooth and thin-walled, each with an often conspicuous periclinal thickening and a reduced, flared collarette. Sporodochial conidia falcate, slightly curved dorsoventrally to almost straight on their ventral faces, broadening in the upper third, tapering towards both ends, with blunt and hooked apical cells and blunt to slightly pointed and extended foot-like basal cells, (4-)5-6(-7)-septate, predominantly five-septate, hyaline, smooth- and thick-walled; four-septate conidia:
(37-)40-55(-56.5) $\times 4.5-5.5 \mu \mathrm{m}($ av. $48.5 \times 5 \mu \mathrm{m})$; fiveseptate conidia: $(46.5-) 51.5-60(-62) \times 4.5-5.5 \mu \mathrm{m}$ (av. $56 \times 5 \mu \mathrm{m})$; six-septate conidia: $55.5-64(-65) \times 4.5-5.5$ $\mu \mathrm{m}$ (av. $60 \times 5 \mu \mathrm{m}$ ); seven-septate conidia: $60.5 \times 5$ $\mu \mathrm{m}$. Chlamydospores subspherical, hyaline to pale yellow, inconspicuously roughened, thick-walled, 5-12 $\mu \mathrm{m}$ diam., single or forming chains or clusters, terminal or intercalary on hyphae.

Culture characteristics: Colonies on PDA reaching 60 $\mathrm{mm}$ diam. at $24^{\circ} \mathrm{C}$ after $7 \mathrm{~d}$ (growth rate: $3.8-4.3 \mathrm{~mm}$ $\left.\mathrm{d}^{-1}\right)$. Colony surfaces pale luteous, amber to pure yellow, flat with abundant dense aerial mycelium in radial patches, cottony to woolly, colony reverse pale luteous to vivid pure yellow. On SNA, colonies white to pale buff, translucent, flat, woolly with scant aerial mycelium, becoming slightly powdery; reverse white to pale buff. On OA, the colonies are pale luteous, pale buff to primrose, flat, membranous to cottony, and colony reverse pale luteous to pale rosy buff.

Notes. In the combined rpb2 and tef1 analysis, Neocosmospora gamtoosensis formed an unsupported lone lineage, basal to a larger lineage containing $N$. hypothe$n e m i, N$. perseae and N. pseudoradicicola. The combined seven-loci analysis resolved $N$. gamtoosensis within the larger lineage, with high statistical support for all the earlier listed species. Base pair similarities between the novel species and its closest relatives ranged from $98 \%$ in the combined dataset to between 96 and $99 \%$ in the individual gene datasets.

Neocosmospora gamtoosensis is morphologically reminiscent of N. hypothenemi, both species having predominantly five-septate macroconidia of very similar size and shape; however, N. gamtoosensis has conspicuously flared collarettes on its aerial phialides, also producing shorter (length up to $11.5 \mu \mathrm{m}$, average $=7 \mu \mathrm{m}$ in $N$. gamtoosensis $v s$ up to $13.5 \mu \mathrm{m}$, average $=8.2 \mu \mathrm{m}$ in $N$. hypothenemi), aseptate aerial conidia, and honey coloured sporodochia (yellow-green in N. hypothenemi), and lacking reddish pigments on PDA. Neocosmospora noneumartii, another genetically distant ( $97 \%$ sequence similarity in the combined analysis), but morphologically similar species, differs from N. gamtoosensis by forming dimorphic conidia from aerial phialides and longer sporodochial conidia (five-septate sporodochial conidia of average length 56 $\mu \mathrm{m} v s 63 \mu \mathrm{m}$ in N. noneumartii). Neocosmospora gamtoosensis is also morphologically very similar to $N$. lerouxii. However, N. gamtoosensis has shorter (five-septate sporodochial conidia average length $63 \mu \mathrm{m}$ in $N$. lerouxii) and more curved sporodochial conidia.

Neocosmospora lerouxii Guarnaccia \& Sand.-Den., sp. nov. - Mycobank MB837942; Figure 7. 

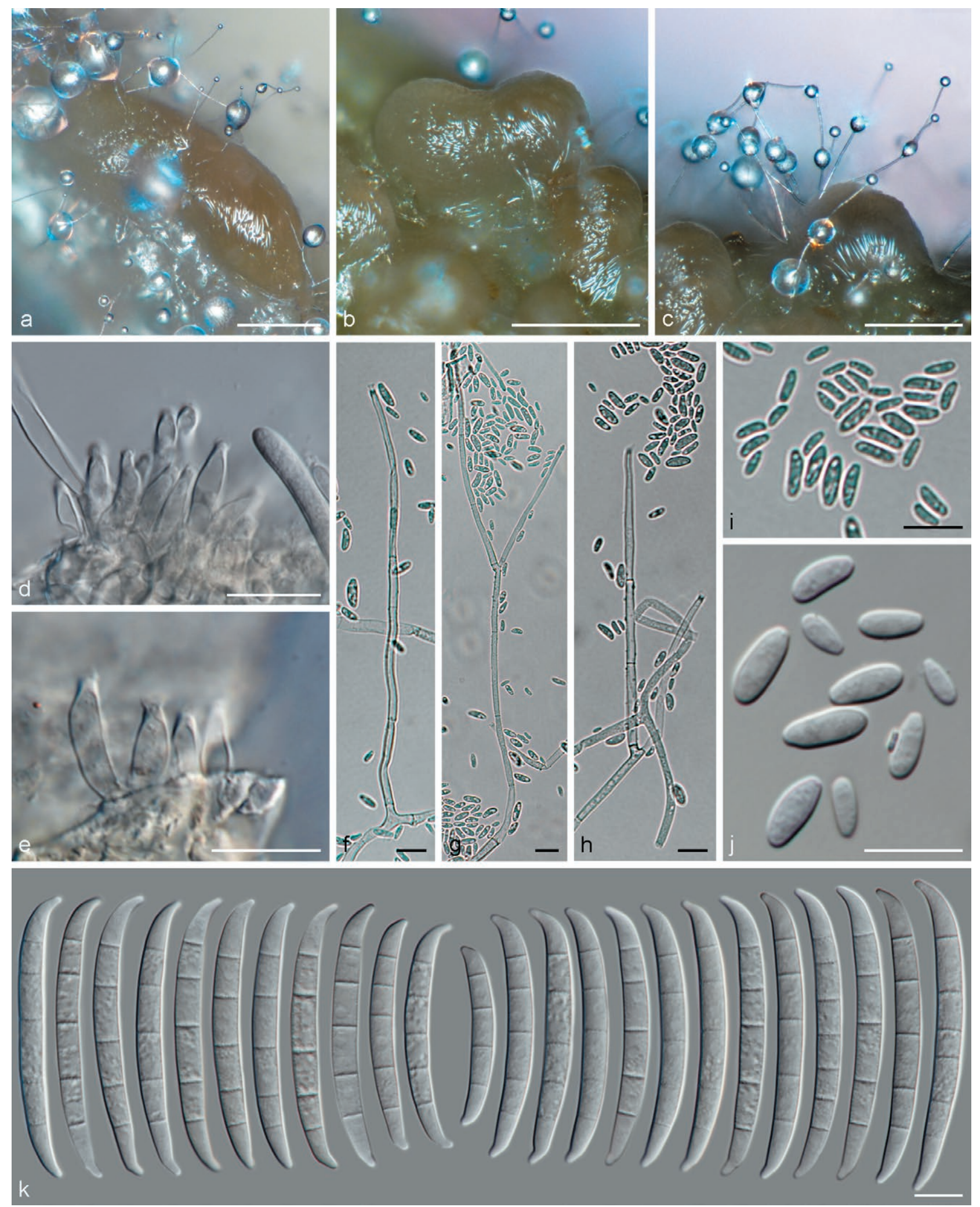

Figure 6. Neocosmospora gamtoosensis (ex-type culture CBS 146502). (a toc) sporodochia formed on the surface of carnation leaves; (d and e) sporodochial conidiophores and phialides; ( $f$ to h) aerial conidiophores; (I and j) aerial conidia; (k) sporodochial conidia. Scale bars: a and $\mathrm{b}=100 \mu \mathrm{m} ; \mathrm{c}$ to $\mathrm{k}=10 \mu \mathrm{m}$. 

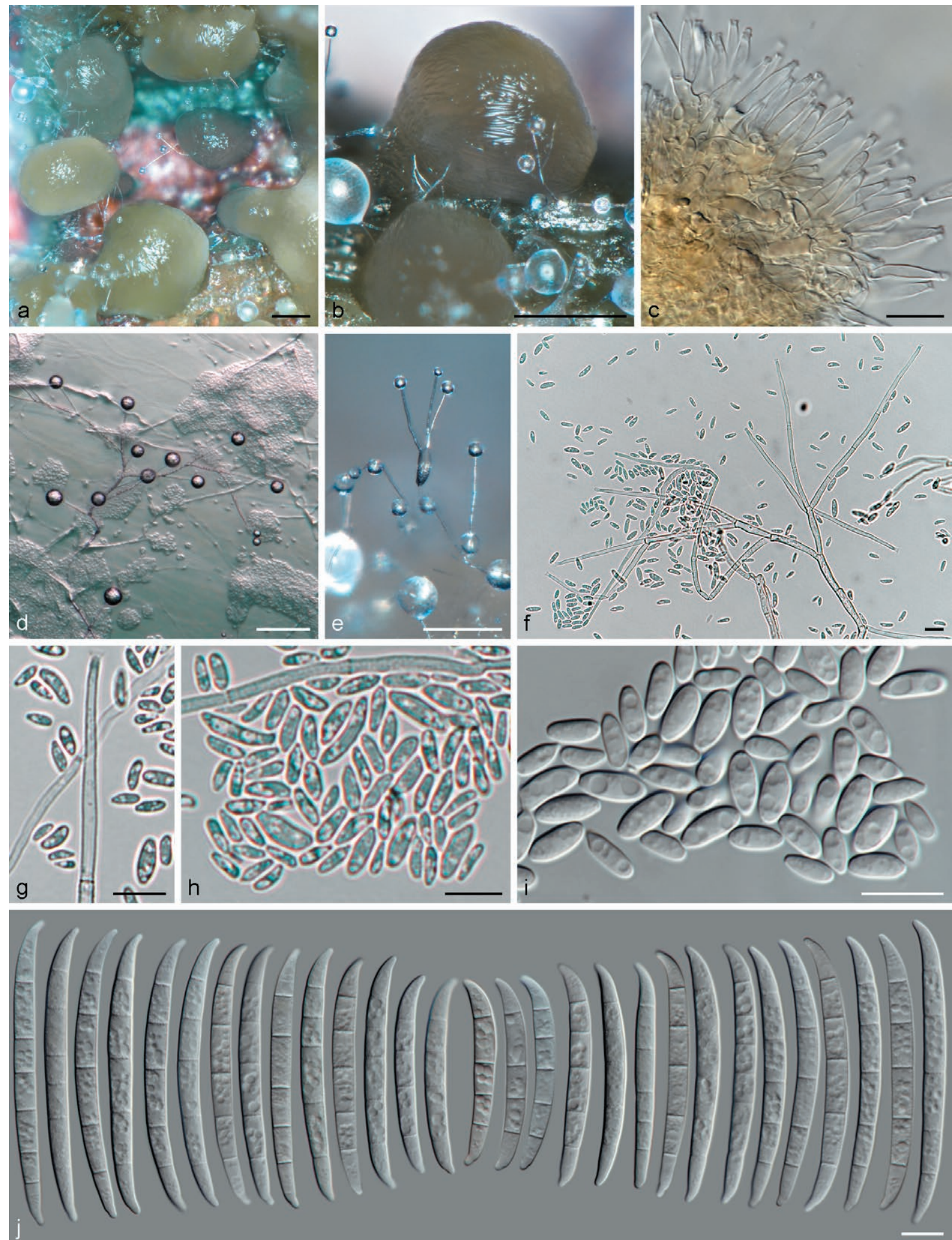

Figure 7. Neocosmospora lerouxii (ex-type culture CBS 146514). (a and b) sporodochia formed on the surface of carnation leaves; (c) sporodochial conidiophores and phialides; ( $\mathrm{d}$ tog) aerial conidiophores and phialides; (h and i) aerial conidia; (j) sporodochial conidia. Scale bars: $\mathrm{a}$ and $\mathrm{b}=100 \mu \mathrm{m} ; \mathrm{d}$ and $\mathrm{e}=50 \mu \mathrm{m} ; \mathrm{f}$ to $\mathrm{j}=10 \mu \mathrm{m}$. 
Etymology. In memory of Dr Hennie Le Roux (10 Jul 1967 - 4 Oct. 2016), who made major contributions to the South African and international citrus industries.

Typus. South Africa, Eastern Cape, Patensie, from Citrus sinensis root scaffold, May 2018, V. Guarnaccia (holotype CBS H-24567 designated here, culture ex-type CBS $146514=$ CPC $37132=$ VG48).

Conidiophores borne on aerial mycelium, 139.5-295 $\mu \mathrm{m}$ long, simple or most commonly abundantly and irregularly branched, proliferating percurrently, bearing terminal single phialides; aerial phialides monophialidic, subulate to subcylindrical, smooth- and thin-walled, 37-61.5 $\times 2-4 \mu \mathrm{m}$, with periclinal thickening and collarettes abundant; aerial conidia arranged in false heads on phialide tips, hyaline, ovate, broadly ellipsoidal to short clavate, smooth- and thin-walled, $0(-1)$-septate,

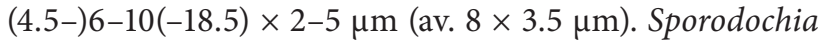
pale luteous, ochreous to citrine, formed abundantly on carnation leaves and on agar surfaces. Sporodochial conidiophores verticillately and laterally branched and densely packed, smooth- and thin-walled, bearing apical whorls of up to four monophialides; sporodochial phialides subulate to subcylindrical, (12-)14.5-19.5(-22.5) $\times$ 2.5-4.5 $\mu \mathrm{m}$, smooth- and thin-walled, with conspicuous periclinal thickening and short, flared collarettes. Sporodochial conidia falcate, almost straight or gently curved dorsiventrally, each broadening in the centre and upper third, tapering towards both ends, with a conical and slightly curved apical cell and a notched foot-like basal cell, (2-)4-6-septate, predominantly five-septate, hyaline, smooth- and thick-walled; two-septate conidia, 29 $\times 4 \mu \mathrm{m}$; three-septate conidia: $40 \times 5 \mu \mathrm{m}$; four-septate conidia: (44-)45-49(-50.5) $\times(4-) 4.5-5 \mu \mathrm{m}$ (av. $47 \times 5$ $\mu \mathrm{m})$; five-septate conidia: $(46.5-) 56.5-67(-73.5) \times 4.5-$ $5(-6.5) \mu \mathrm{m}$ (av. $62 \times 5 \mu \mathrm{m})$; six-septate conidia: $60-74 \times$ 4.5-5.5 $\mu \mathrm{m}$ (av. $67 \times 5 \mu \mathrm{m})$. Chlamydospores subspherical to spherical, hyaline to pale yellow-brown, smooth- and thick-walled, $4-8 \mu \mathrm{m}$ diam., single or in chains, terminal or intercalary on hyphae.

Culture characteristics. Colonies on PDA reaching 61 $\mathrm{mm}$ diam. at $24^{\circ} \mathrm{C}$ after $7 \mathrm{~d}$ (growth rate: $3.5-4.3 \mathrm{~mm}$ $\mathrm{d}^{-1}$ ). Surfaces buff, pale luteous to pale flesh, with abundant and dense whitish aerial mycelium, flat to slightly raised, felty to cottony. Colony reverse pale luteous, quickly becoming amber to sulphur yellow, with or without pale apricot patches. On SNA, colonies white and translucent, flat, felty, with white reverse sides. On OA, colonies white, saffron to buff, flat, membranous to cottony, with reverse sides buff to pale luteous with pale salmon patches.

Notes. The combined $r p b 2$ plus tef1 analysis showed this taxon to form a well-supported $(\mathrm{BS}=74, \mathrm{PP}=0.96)$ lone lineage, basal to a larger, unsupported linage containing $N$. catenata, N. cyanescens, $N$. ferruginea, $N$. macrospora, and N. spathulata, and the undescribed phylogenetic species FSSC 12. The analysis of the combined seven-gene dataset confirmed the previous results, with all the species described here resolved as highly- to fully-supported monophyletic clades. Genetic similarity between $N$. lerouxii and its closest phylogenetic relatives also support phylogenetic exclusivity of N. lerouxii $(98 \%$ sequence similarity with all the above taxa in the combined alignment, and 97 to $99 \%$ similarity for the individual gene datasets).

Morphologically, Neocosmospora lerouxii most closely resembles the three distantly related species N. gamtoosensis, N. hypothenemi and N. noneumartii (respectively, 97, 98 and 97\% sequence similarity, in the seven-loci combined dataset). While the three species were clustered in well-separated lineages in all analyses, morphologically they share very similar characteristics. Although $N$. lerouxii has similar macroconidial shape to N. gamtoosensis and N. hypothenemi, the macroconidia of $N$. lerouxii are longer and straighter than in the other two species (five-septate macroconidia average length $62 \mu \mathrm{m} v s 56 \mu \mathrm{m}$ in $N$. gamtoosensis and $59 \mu \mathrm{m}$ in $N$. hypothenemi). Macroconidia of $N$. lerouxii also have thinner walls in comparison to those of $N$. noneumartii. In addition, has a slower growth rate in culture than $N$. noneumartii, (3.5-4.3 $\mathrm{mm} \mathrm{d}^{-1}$ for $N$. lerouxii vs $4.7-8$ $\mathrm{mm} \mathrm{d}^{-1}$ in $\mathrm{N}$. noneumartii).

\section{DISCUSSION}

Since 2013, severe sudden decline and death of citrus plants has been observed in citrus production areas of the Eastern Cape province of South Africa. Several species of Colletotrichum, Diaporthaceae and Botryosphaeriaceae have been reported as causing wood decay of citrus plants internationally (Guarnaccia and Crous, 2018; Mayorquin et al., 2019; Berraf-Tebbal et al., 2020; Esparham et al., 2020; Bezerra et al., 2021). Considering the very large economic losses to the South African citrus industry due to the observed sudden decline of trees, and because no surveys and isolations had been previously conducted for this disease and associated pathogens in the Eastern Cape citrus production area, a large-scale survey of affected citrus plants was required. The present study provides the first preliminary survey and sampling of citrus trees affected by dry root rot, and characterization of Neocosmospora diversity related to the observed disease in two important citrus production areas of South Africa. 
Neocosmospora species are well-established in geographical areas with Mediterranean, sub-tropical or tropical climates, where these fungi are associated with diseases of important agricultural crops (Sandoval-Denis et al., 2018; Guarnaccia et al., 2018; 2019).

Fusarium oxysporum, F. proliferatum and N. solani s. str. were previously considered as pathogens associated with dry root rot of citrus plants. (Menge, 1988; Adesemoye et al., 2011). Specifically F. oxysposrum and $N$. solani were previously reported from South Africa. Diversity of Fusarium (three species) and Neocosmospora (five species) was revealed associated with dry root rot in restricted areas of three European countries by Sandoval-Denis et al. (2018). However, that study considered it likely that many other Neocosmospora spp. would also be isolated if a wider sampling area was surveyed.

In the present study, several citrus orchards in two major citrus production area of South Africa were investigated. A total of 62 Neocosmospora strains were collected from symptomatic tree trunks, roots and soil surrounding the roots. Phylogenetic analyses as well as morphological characters, revealed ten Neocosmospora species associated with infections on Citrus in South Africa, plus one species (N. falciformis) from soil from affected citrus orchards. The analyses included several of the closest related taxa to each of the Neocosmospora species recovered, based on BLAST searches of NCBI's GenBank nucleotide database. The final phylogenetic tree revealed four previously undescribed species (N. addoensis, N. citricola, N. gamtoosensis, and N. lerouxii) and six known species (N. brevis, N. crassa, N. ferruginea, N. hypothenemi, N. noneumartii, and $N$. solani) all of which were always associated with abovementioned symptomatic material.

Neocosmospora citricola, $N$. ferruginea and $N$. solani were the predominant species, largely found associated with the affected tissues of symptomatic plants cultivated in all the investigated orchards. Although follow-up studies will conduct pathogenicity trials to confirm these observations, it is assumed that these species represent the major biotic factors causing DRR of citrus in South Africa as they were consistently associated with the symptoms described from the diseased trees. These results also partially confirm what was recently demonstrated after surveys conducted in Mediterranean countries, where $N$. ferruginea (formerly FSSC28) and N. solani were isolated from typical DRR of citrus (Sandoval-Denis et al., 2018). Neocosmospora citricola was not found before the present study, and considering the broad distribution on affected plants, this fungus is likely to be important in DRR. Neocosmospora addoensis was isolated with low frequency, from one orchard and from necrotic trunk tissue. The other novel species described in this study, N. gamtoosen- sis and N. lerouxii, were found only sporadically, and are thus not considered as important pathogens. However, their description provides new insights into the taxonomy of Neocosmospora. Neocosmospora brevis, N. crassa, N. hypothenemi and $N$. noneumartii were also isolated sporadically, and future studies will investigate their roles in DRR. The complexity of pathogens associated with artificially reproducing DRR of citrus is well-known (Graham et al., 1985), but needs to be confirmed in further field trials. Furthermore, additional surveys in South Africa and other citrus-producing areas, and pathogenicity trials of Neocosmospora spp. in association with abiotic factors, should also be conducted.

The present study has provided the first overview of Neocosmospora diversity associated with DRR of citrus trees in South Africa, and has given useful information about taxonomic characterization within Neocosmospora. All the Neocosmospora species were isolated from crowns, trunks, roots and soil from the affected citrus orchards. Infected propagation material and soil can spread the pathogens nationally and internationally as the fungi can survive as chlamydospores in the soil and systemic infections in plant material. Further studies are required to resolve the host range and pathogenicity of all the species recovered. These fungi can survive as endophytes or as latent infections within citrus plants, so healthy propagation material should be used by growers. Favourable climatic conditions and, especially, plant stress factors could also play major roles in disease development. Further research on the epidemiology of DRR of citrus should be conducted to develop specific knowledge as the basis for effective disease prevention and management.

\section{LITERATURE CITED}

Adesemoye A.O., Eskalen A., Faber B., Bender G., O'connell N., ... Shea, T. 2011. Current knowledge on Fusarium dry root rot of citrus. Citrograph 2: 29-33.

Bender G.S. 1985. Dry Root Rot of Citrus-Factors Which Increase the Susceptibility of Trees to Infection by Fusarium solani. $\mathrm{PhD}$ dissertation, University of California, Riverside, CA, USA.

Berraf-Tebbal A., Mahamedi A.E., Aigoun-Mouhous W., Špetík M., Čechová J., ... Eichmeier A. 2020. Lasiodiplodia mitidjana sp. nov. and other Botryosphaeriaceae species causing branch canker and dieback of Citrus sinensis in Algeria. PloS one 15: e0232448.

Bezerra J.D.P, Crous P.W., Aiello D., Gullino M.L., Polizzi G., Guarnaccia V. 2021. Genetic diversity and pathogenicity of Botryosphaeriaceae species aassociated with symptomatic citrus in Europe. Plants 10: 492. 
Broadbent P. 2000. Dry root rot or sudden death. In: Timmer LW, Garnsey SM, Graham JH (eds) Compendium of Citrus Diseases, 2nd edn. APS Press, St. Paul, p. 71

Carbone I., Kohn L.M. 1999. A method for designing primer sets for speciation studies in filamentous ascomycetes. Mycologia 91: 553-556.

Conzulex W., Ramallo J., Ploper L.D. 1997. Identification of Fusarium solani (Mart.) associated with decline and root rot of grapefruit (Citrus paradisi). Avana Agroindustrial 18: 7-8.

Crous P.W., Verkley G.J.M., Groenewald J.Z., Houbraken, J. 2019. Westerdijk Laboratory Manual Series 1: Fungal Biodiversity. Westerdijk Fungal Biodiversity Institute, Utrecht, The Netherlands.

Derrick K.S., Timmer L.W. 2000. Citrus Blight and other diseases of recalcitrant etiology. Annual Review of Phytopathology 38: 181-205.

El-Mohamedy R.S.R. 1998. Studies on Wilt and Root Rot Disease of Some Citrus Plants in Egypt. PhD thesis, Fac Agric Ain Shams Univ, Cairo, Egypt, 227 pp.

Esparham N., Mohammadi H., Gramaje D. 2020. A survey of trunk disease pathogens within citrus trees in Iran. Plants 9: 754.

Fang D.Q., Federici C.T., Roose M.L. 1998. A highresolution linkage map of the citrus tristeza virus resistance gene region in Poncirus trifoliata (L.) Raf. Genetics 150: 883-890.

FAOSTAT 2019. Food and Agriculture Organization of the United Nations. http://www.fao.org/faostat/ en/\#home. Accessed 26 February 2020.

Fisher N.L., Burguess L.W., Toussoun T.A., Nelson P.E. 1982. Carnation leaves as a substrate and for preserving cultures of Fusarium species. Phytopathology 72: 151-153.

Gräfenhan T., Schroers H.J., Nirenberg H.I., Seifert K.A. 2011. An overview of the taxonomy, phylogeny, and typification of nectriaceous fungi in Cosmospora, Acremonium, Fusarium, Stilbella, and Volutella. Studies in Mycology 68: 79-113.

Graham J.H., Brlansky R.H., Timmer L.W., Lee R.F., Marais, L.J. 1985. Comparison of citrus tree declines with necrosis of major roots and their association with Fusarium solani. Plant Disease 69: 1055-1058.

Guarnaccia V., Crous P.W. 2018. Species of Diaporthe on Camellia and Citrus in the Azores Islands. Phytopathologia Mediterranea 57: 307-319.

Guarnaccia V., Sandoval-Denis M., Aiello D., Polizzi G., Crous, P.W. 2018. Neocosmospora perseae sp. nov., causing trunk cankers on avocado in Italy. Fungal Systematics and Evolution 1: 131-140.

Guarnaccia V., Aiello D., Polizzi G., Crous, P.W., Sandoval-Denis M. 2019. Soilborne diseases caused by Fusa- rium and Neocosmospora spp. on ornamental plants in Italy. Phytopathologia Mediterranea 58: 127-137.

Hannachi I., Rezgui S., Cherif M. 2014. First report of mature citrus trees being affected by Fusarium wilt in Tunisia. Plant Disease 98: 566.

Huelsenbeck J.P., Ronquist F. 2001. MrBayes: Bayesian inference of phylogeny. Bioinformatics 17: 754-755.

Katoh K., Rozewicki J., Yamada K.D. 2019. MAFFT online service: multiple sequence alignment, interactive sequence choice and visualization. Briefings in Bioinformatics 20: 1160-1166.

Kore S.S., Mane A.V. 1992. A dry root rot disease of kagzilime (Citrus aurantifolia) seedling caused by Fusarium solani. Journal of Maharashtra Agricultural Universities 17: 276-278.

Kurt Ş., Uysal A., Soylu E., Kara M., Soylu S. 2020. Characterization and pathogenicity of Fusarium solani associated with dry root rot of citrus in the eastern Mediterranean region of Turkey. Journal of General Plant Pathology 86: 326-332.

Leslie J.F., Summerell B.A. 2006. The Fusarium laboratory manual. Blackwell Publishing, Ames.

Liu Y.J., Whelen S., Hall B.D. 1999. Phylogenetic relationships among ascomycetes: evidence from an RNA polymerase II subunit. Molecular Biology and Evolution 16: 1799-1808.

Lombard L., Van der Merwe N.A., Groenewald J.Z., Crous P.W. 2015. Generic concepts in Nectriaceae. Studies in Mycology 80: 189-245.

Malikoutsaki-Mathioudi M., Bourbos V.A., Skoudridakis M.T. 1987. La pourriture sèche des racines - une maladie très grave des agrumes en Grèce. EPPO Bulletin 17: 335-340.

Mason-Gamer R., Kellogg E. 1996. Testing for phylogenetic conflict among molecular data sets in the tribe Triticeae (Gramineae). Systematic Biology 45: 524545.

Mayorquin J.S., Nouri M.T., Peacock B.B., Trouillas F.P., Douhan G.W., ... Eskalen A. 2019. Identification, Pathogenicity, and Spore Trapping of Colletotrichum karstii associated with twig and shoot dieback in California. Plant Disease 103: 1464-1473.

Menge J.A. 1988. Dry root rot. In: Whiteside JO, Garnsey SM, Timmer LW (eds), Compendium of Citrus diseases, 14-15. APS Press, USA.

Miller M.A., Pfeiffer W., Schwartz T. 2012. The CIPRES science gateway: enabling high-impact science for phylogenetics researchers with limited resources. In: Proceedings of the 1st Conference of the Extreme Science and Engineering Discovery Environment: Bridging from the extreme to the campus and beyond, 1-8. Association for Computing Machinery, USA. 
Nemec S., Baker R. 1992. Observations on Fusarium solani naphthazarin toxins, their action, and potential role in citrus plant disease. Proceedings of the 7 th meeting of the International Society of Citriculture, Acireale, Italy, International Society of Citriculture, Riverside, pp. 832-837.

Nemec S., Baker R., Burnett H. 1980. Pathogenicity of Fusarium solani to citrus roots and its possible role in blight etiology. Proceedings of the Florida State Horticultural Society 93: 36-41.

Nirenberg H.I. 1976. Untersuchungen über die morphologische und biologische differenzierung in der Fusarium-Sektion Liseola. Mitteilungen der Biologischen Bundesanstalt für Land- und Forstwirtschaft BerlinDahlem 169: 1-117.

Nylander J.A.A. 2004. MrModeltest v2. Program distributed by the author. Evolutionary Biology Centre, Uppsala University.

O'Donnell K., Sutton D.A., Fothergill A., McCarthy D., Rinaldi M.G., ... Geiser D.M. 2008. Molecular phylogenetic diversity, multilocus haplotype nomenclature, and in vitro antifungal resistance within the Fusarium solani species complex. Journal of Clinical Microbiology 46: 2477-2490.

O’Donnell K, Sutton DA, Rinaldi MG, Sarver, B. A., Balajee, S. A., ... Aoki T. 2010. Internet-accessible DNA sequence database for identifying fusaria from human and animal infections. Journal of Clinical Microbiology 48: 3708-3718.

Polizzi G., Magnano di San Lio G., Catara A. 1992. Dry root rot of citranges in Italy. Proceedings of the International Society of Citriculture. VII International Citrus Congress, Acireale 1992: 890-893.

Quaedvlieg W., Binder M., Groenewald J.Z., Summerell, B.A., Carnegie, A.J., ... Crous P.W. 2014. Introducing the consolidated species concept to resolve species in the Teratosphaeriaceae. Persoonia 33: 1-40.

Rayner R.W., 1970. A Mycological Colour Chart. Kew, UK: Commonwealth Mycological Institute.

Rehman A., Rehman A., Javed N., Mehboob S. 2012. Toxin production by Fusarium solani from declining citrus plants and its management. African Journal of Biotechnology 11: 2199-2203.

Ronquist F., Huelsenbeck J.P. 2003. MrBayes 3: Bayesian phylogenetic inference under mixed models. Bioinformatics 19: 1572-1574.

Sandoval-Denis M., Crous P.W. 2018. Removing chaos from confusion: assigning names to common human and animal pathogens in Neocosmospora. Persoonia 41: 109-129.

Sandoval-Denis M., Guarnaccia V., Polizzi G., Crous P.W. 2018. Symptomatic Citrus trees reveal a new pathogenic lineage in Fusarium and two new Neocosmospo- ra species. Persoonia 40: 1-25.

Sandoval-Denis M., Lombard L., Crous P.W. 2019. Back to the roots: a reappraisal of Neocosmospora. Persoonia 43: 90-185.

Smith I.M., Dunez J., Phillips D.H., Lelliott R.A., Archer S.A. 1988. European handbook of plant diseases. Blackwell Scientific Publications, UK.

Spina S, Coco V, Gentile A, Catara A., Cirvilleri G. 2008. Association of Fusarium solani with rolabc and wild type Troyer Citrange. Journal of Plant Pathology 90: 479-486.

Stamatakis A. 2014. RAxML version 8: a tool for phylogenetic analysis and post-analysis of large phylogenies. Bioinformatics 30: 1312-1313.

Sung G.H., Sung J.M., Hywel-Jones N.L., Spatafora J. W. 2007. A multi-gene phylogeny of Clavicipitaceae (Ascomycota, Fungi): Identification of localized incongruence using a combinational bootstrap approach. Molecular Phylogenetics and Evolution 44: 1204-1223.

Tamura K., Stecher G., Peterson D., Filipski A., Kumar S. 2013. MEGA6: Molecular Evolutionary Genetics Analysis version 6.0. Molecular Biology and Evolution 30: 2725-2729.

Timmer L.W. 1982. Host range and host colonization, temperature effects, and dispersal of Fusarium oxysporum f. sp. citri. Phytopathology 72: 698-702.

Timmer L.W., Garnsey S.M., Grimm G.R., El-Gholl N.E., Schoulties C.L. 1979. Wilt and dieback of Mexican lime caused by Fusarium oxysporum. Phytopathology 69: 730-734.

Verma K.S., Nartey S., Singh N. 1999. Occurrence and control of dry root rot of citrus seedlings. Plant Disease Research 14: 31-34.

Vilgalys R., Hester M. 1990. Rapid genetic identification and mapping of enzymatically amplified ribosomal DNA from several Cryptococcus species. Journal of Bacteriology 172: 4238-4246.

Vilgalys R., Sun B.L. 1994. Ancient and recent patterns of geographic speciation in the oyster mushroom Pleurotus revealed by phylogenetic analysis of ribosomal DNA sequences. Proceedings of the National Academy of Sciences of the United States of America 91: 4599-4603.

White T.J., Bruns T., Lee S., Taylor J. 1990. Amplification and direct sequencing of fungal ribosomal RNA genes for phylogenetics. In: Innes MA, Gelfand DH, Sninsky et al. (eds), PCR Protocols: a Guide to Methods and Applications: 315-322. Academic Press, USA.

Wiens J.J. 1998. Testing phylogenetic methods with tree congruence: phylogenetic analysis of polymorphic morphological characters in phrynosomatid lizards. Systematic Biology 47: 427-444.

Yaseen T., D’Onghia A.M. 2012. Fusarium spp. associated to citrus dry root rot: An emerging issue for Mediterranean citriculture. Acta Horticulturae 940: 647-655. 